
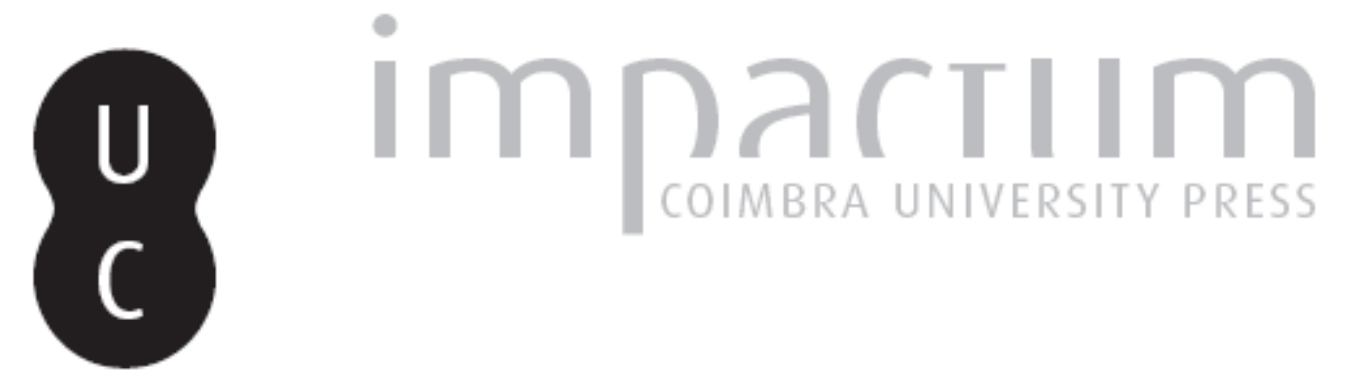

\title{
Domingos Vandelli e a Revolução Francesa
}

\author{
Autor(es): Jobim, Leopoldo Collor
}

Publicado por: Imprensa da Universidade de Coimbra

URL persistente:

URl:http://hdl.handle.net/10316.2/43772

DOI:

DOI:https://doi.org/10.14195/2183-8925_10_13

Accessed : $\quad$ 26-Apr-2023 10:43:07

A navegação consulta e descarregamento dos títulos inseridos nas Bibliotecas Digitais UC Digitalis, UC Pombalina e UC Impactum, pressupõem a aceitação plena e sem reservas dos Termos e Condições de Uso destas Bibliotecas Digitais, disponíveis em https://digitalis.uc.pt/pt-pt/termos.

Conforme exposto nos referidos Termos e Condições de Uso, o descarregamento de títulos de acesso restrito requer uma licença válida de autorização devendo o utilizador aceder ao(s) documento(s) a partir de um endereço de IP da instituição detentora da supramencionada licença.

Ao utilizador é apenas permitido o descarregamento para uso pessoal, pelo que o emprego do(s) título(s) descarregado(s) para outro fim, designadamente comercial, carece de autorização do respetivo autor ou editor da obra.

Na medida em que todas as obras da UC Digitalis se encontram protegidas pelo Código do Direito de Autor e Direitos Conexos e demais legislação aplicável, toda a cópia, parcial ou total, deste documento, nos casos em que é legalmente admitida, deverá conter ou fazer-se acompanhar por este aviso.

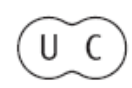


REVISTA DE HISTORIA DAS IDEIAS IO
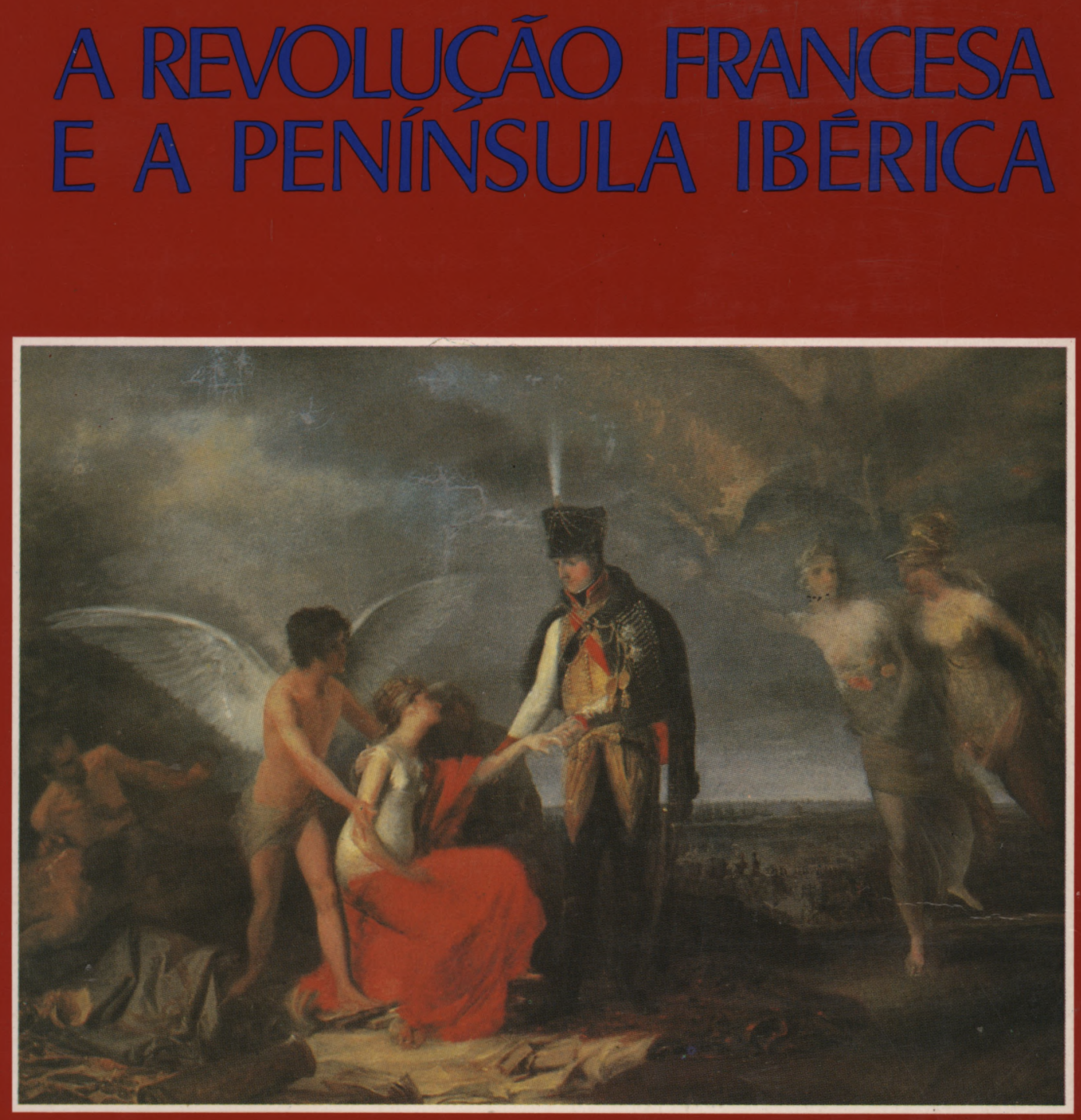

INSTITUTO DE HISTÖRIA E TEORIA DAS IDEIAS FACULDADE DE LETRAS 


\section{LEOPOLDO COLLOR JOBIM *}

\section{DOMINGOS VANDELLI \\ E A REVOLUÇÃO FRANCESA}

Pretendo estudar nesta comunicação as posições assumidas por Domingos Vandelli em 1796 e 1797 face às opções políticas que se apresentavam à Coroa portuguesa, confrontada com o expansionismo ideológico e militar da Revolução Francesa. Para tal, examinarei alguns textos inéditos de sua autoria.

Acredito que esses textos ajudem a compreender as ideias políticas de Vandelli e da elite dirigente portuguesa, contribuindo para o melhor conhecimento da última etapa do antigo regime em Portugal. O seu roteiro de vida e de pensamento - pelas múltiplas e importantes funções que exerceu, pela corrente ideológica de que era intérprete, por suas contribuições para o processo de actualização da cultura científica portuguesa, por sua intimidade com o poder, (o que lhe facultava o acesso a informações reservadas e lhe fornecia uma perspectiva a partir do interior do processo decisório) - esclarece a mecânica do poder e a importância da colaboração dos intelectuais no exercício desse poder.

Domingos Vandelli é uma personalidade controvertida, tanto em termos políticos como científicos. Conselheiro íntimo de D. João, gozando «daquela confiança e segurança que o amável e adorável Príncipe me permite» (m. 28/28), vem a ser castigado por trair a Coroa; sendo um intelectual prestigiado pelo poder, é acusado por seus pares de incompetência e de falta de rigor científico ${ }^{(\mathbf{1}}$ ).

* Bolseiro do CNPQ (Brasil)

(1) Manoel Joaquim Henriques de Paiva, médico e naturalista muito actuante no ambiente científico do fim do século, publica, no Jornal Encyclopedico, Lisboa, Julho 1788, uma crítica à Florae Lusitanicae et Brasiliensis Specimen, Conimbricae, 1788, de Vandelli. João da 
Expulsos os franceses, vai exilado em 1810 para os Açores e depois para a Inglaterra em decorrência da «setembrizada» $\left({ }^{2}\right)$. Volta do exílio já senil, morrendo pouco depois. As razões de sua condenação nunca foram explicadas, (assim como a de muitos outros acusados de colaboracionismo ou adesão às ideias francesas), o que não é de admirar tendo-se em conta a pressão popular anti-francesa e outros factores que condicionavam os julgamentos ou as punições $\left(^{3}\right)$.

Não me deterei aqui em nenhum aspecto específico de sua vida - alguns dos quais já anteriormente estudados $\left({ }^{4}\right)$ nem

Silva Feijó, discípulo de D.V., refuta-as as Reflecções botanicas sobre a censura do Jornal Encyclopedico d Florae Lusitanicae.... $\mathrm{O}$ viajante inglês Link aponta o seu método pouco científico de classificar plantas. Henry Frederick Link, Travels in Portugal, London, 1801, p. 129.

(2) Surto de repressão a elementos considerados afrancesados ou mações, deflagrado na noite de 10 para 11 de Setembro de 1810, ouando chegou a Lisboa a notícia da tomada de Almeida por Massena. Us governadores do Reino aproveitaram a situação de pânico e a opinião pública anti-francesa para afastar alguns suspeitos. Em decorrência da instalação desses exilados em Londres intensificou-se a propaganda liberal através de jornais editados no estrangeiro. A maioria dos banidos voltou em 1814, por iniciativa dos próprios governadores do Reino, mas alguns só regressaram depois de 9/2/1820, quando as Cortes autorizaram a volta de todos os portugueses ainda exilados.

(3) Conforme apontei em comunicação apresentada à primeira parte deste Colóquio em Madrid: "Lealdade e traição: um estudo sobre is condicionamentos políticos dos intelectuais afrancesados em Portugal (1808-1810)», in Actas del Coloquio Internacional La Revolución Francesa y la Península Ibérica, Madrid, 1987.

(4) Nascido em Pádua, em 1735, filho de um professor de medicina da Universidade, veio para Portugal em 1763. Em 1772, a convite do Marauês de Pombal, é nomeado para reger a cátedra de Filosofia em Coimbra. Neste país acumulou empregos e honrarias: comendador da Ordem de Cristo, deputado da Real Junta do Comércio, Agricultura e Fábricas, sucessivamente director dos jardins botânicos da Ajuda (1768) e de Coimbra (1774), sócio fundador e um dos mais actuantes membros da Academia Real das Ciências de Lisboa (a partir de 1779). Patrocinou viagens filosóficas às colónias, inclusive ao Brasil, publicou livros de botânica e física e não poucas memórias sobre agricultura, além de uma flora do Brasil e Portugal. Morreu em 27/6/1816. Para certos aspectos da sua biografia, cf. António Rosa Mendes, "O naturalista Domingos Vancielli. Novos elementos para a sua biografian; Clio. Revista da Universidade de Lisboa, 5, 1984-85, pp. 103 e ss., Lígia Cruz, "Domingos Vandelli, alguns aspectos da sua actividade em Coimbra», Boletim do Arquivo da Universidade de Coimbra, 2, 1976, pp. 21-27; Biagio Longo, "Domenico Vandelli e la fondazione del primo orto botanico nel Portogallo», Relaz,one storiche fra l'Italia e il Portogallo. Memorie e documenti, Roma, Reale Academia d'Italia, 1940, pp. 403 e ss.; Guido Batelli, Domenico Vandelli e il giardino botanico di Coimbra (Sep. de Biblos), Coimbra, 1929: Pietro Andrea Saccardo, Il Dr. Domenico Vandelli e della parte ch'ebbe lo studio padovano nella riforma dell'istruzione del Portogallo nel settecento, Padova, 1899. 
em sua produção científica ou suas numerosas e absorventes responsabilidades burocráticas $\left({ }^{5}\right)$.

Como disse, vou tratar de entender o seu posicionamento frente à Revolução Francesa através da análise de uma série de pareceres e memórias que encontrei na Torre do Tombo $\left(^{6}\right)$. Creio que esses textos sejam desconhecidos dos pesquisadores: são quase oitenta escritos, elaboradcs entre 1796 e 1806, sobre finanças, desenvolvimento económico, imigração de judeus, política externa, alastramento das ideias jacobinas e as diversas e concorrentes tendências políticas nesse conturbado fim de século.

Constituem uma fonte preciosa para a compreensão da época e revelam-nos uma faceta de Vandelli pouco conhecida: o político, o conselheiro do rei, a par das maquinações da diplomacia e das intrigas de Queluz, dos deslocamentos e dos efectivos dos exércitos das diversas potências, das alternativas políticas que se ofereciam ou recusavam aos dirigentes europeus, das vantagens e desvantagens das possíveis alianças dinásticas, comerciais ou militares $\left({ }^{7}\right)$.

Alguns trazem a data completa, mas a maioria indica apenas 0 ano em que foram escritos. Muitas vezes não passam de apontamentos, rascunhos de pareceres, notas sucintas ¿parentemente para uso futuro; algumas estão formalmente

(5) Em 1795 é dispensado de atender pessoalmente a certos Encargos administrativos por estar sobrecarregado de «ocupações do Real Serviço». ANTT, determinação régia de 6/5/1795. Reino, maço 444 (ms).

${ }_{(6)}$ Esses manuscritos foram levados para o Brasil em 1807 e encontram-se no Arquivo Nacional do Rio de Janeiro; seus facsímiles foram enviados para a Torre do Tombo há aproximadamente vinte anos, no contexto de um programa de troca de documentação já desactivado. Em Lisboa estão encadernados em três códices (livros 28, 29 e 30), do fundo Documentos vindos do Brasil A organização que os arquivistas brasileiros deram ao material é muito deficiente. No índice foram desprezados os títulos dados por Vandelli aos textos sendo substituídos por «memória sobre tal assunto". Como estão numerados em sequência, para cada livro, para simplificar a identificação, as citações vêm seguidas do número da memória e do livro, entre parêntesis.

(7) Há outros escritos de Vandelli encontrados e adquiridos por Mosés Amzalak em 1942. Vinham numa pasta que trazia escrito na capa "Vandelli q. tratão dos nepresentes do Erario escrito em 3 de Fevereiro de 1804" e são cartas, memórias, avisos e lembranças sobre finanças públicas portuguesas. Foi impossível localizar esse acervo, mas um deles, de 1 de Janeiro de 1804, foi publicado apud Moses Amzalak, Alguns alvitres de Domingos Vandelli sobre finanças dados ao Príncipe Regente D. João (Sep. da Revista de Contabilidade e Comércio), Porto, 1942. 


\section{Revista de História das Ideias}

completas $\left({ }^{8}\right)$ e parecem redigidas por encomenda do Príncipe Regente, embora esse destinatário raramente venha explicitado. Refere-se ao que «S. A. R. me fez a honra de me mandar comunicar.... (m. 12/28), a "honra que V.A.R. me faz em aceitar com benignidade as minhas reflexões» (m. 19/29) ou em "pedir c meu parecer» (m. 18/29) e, alhures, especifica que escreve para o Príncipe, «a quem comunicarei o resultado de todos os meus estudos, meditações e reflexões....» (m. 28/28). Mas fica a certeza do acesso fácil, constante e directo a D. João.

$\mathrm{Na}$ maioria das vezes, a justificativa para escrever estes textos é vaga e mesmo evasiva: «tenho brevemente tratado sobre diversos pontos políticos que não pertencem a minha profissão, movido de entusiasmo patriótico, embora sem luzes para problemas tão graves», (m. 40/28) e "estas minhas confusas reflexões.... (só) servirão para avivar-lhe (ao Príncipe) as ideias....» (m. 1/29).

Mas, o que logo à primeira leitura chama a atenção, é que as suas reflexões nada têm de "confusas». Antes pelo contrário. f́. naturalmente nas memórias «acabadas» (completamente desenvolvidas) onde se nota (melhor do que nos apontamentos ou rascunhos) o tratamento dos assuntos e a maneira pela qual estrutura o seu pensamento. Transplanta para o discurso político as exigências do discurso científico, distribuindo os assuntos e expondo o tema de acordo com o objectivo que introduz o escrito. Utiliza uma linguagem clara, nada ambígua, com termos precisos. Não é um estilista, mas expõe bem, escorreitamente, e o seu raciocínio, parte de premissas explícitas para chegar às conclusões almejadas. Depois de apresentar as razões que o levam a adoptar uma determinada opinião, diz que «a vista do exposto.... se poderá concluir» isto ou aquilo.

No texto «Economia das finanças» afirma que «a humana inteligência é muito limitada para abranger ofícios multiplicados e combinados sem antes arranjá-los em sistema, simplificando-os» (m. 2/30). Para ele, é «indispensável o sistema em tudo» (m. $7 / 29)$ - inclusive e sobretudo para a política. O correcto ordenamento do enunciado é de suma importância, pois a verdade é fruto dessa operação mental: «qualquer sábio dos mais ignorantes às vezes apreende coisas que não tinha observado em novas combinações de ideias para resolver dificultoso problema

(8) Entre alguns escritos «acabados» indicamos: "Pronóstico político» (m. 15/30); "Plano para a erecção de um Banco Real em Lisboa» (m. 20/30); "Doença política» (m. 15/29); «Plano económico» (m. 3/30) ou a "Memória», sem título, (m. 7/29). 
de aritmética política» (m.7/29). Apesar da falsa modéstia do «mais ignorante» dos cientistas, sobressai a ideia base: «as combinações de ideias», desde que embasadas em uma metodologia científica, legitimam a competência para organizar politicamente o mundo.

Vandelli tem uma ideia muito precisa do que ainda pode ser feito para salvar a monarquia e indigna-se com a indiferença, incúria e falta de determinação dos ministros que ignoram a dramaticidade do problema. Vê com toda a lucidez que está em jogo a existência mesma de Portugal enquanto nação soberana e propõe medidas enérgicas para assegurá-la.

Nestes textos, Vandelli aborda algumas questões de forma mais insistente. Podemos agrupá-las por assuntos, seleccionando as que dizem respeito aos temas de que iremos tratar. São:

1) o estado das finanças portuguesas. Posto que não resta qualquer esperança de um empréstimo estrangeiro ou nacional para atender ao enorme déficit público, examina os diversos novos tributos lançados ou a serem lançados; expõe o estado geral das finanças, seus defeitos e os meios de aumentar a receita pública;

2) a centralização do poder. Propõe adoptar uma política clara e decidida, sem compromissos, entregando a sua execução e a defesa do Reino a uma só pessoa;

3) a opção entre as alianças inglesa e francesa. Estuda a conveniência de Portugal fazer a paz com a República Francesa ou manter a aliança com a Inglaterra e, neste último caso, questiona a possibilidade da Inglaterra ser capaz de fornecer a ajuda necessária ao Reino para repelir os inimigos e salvar-se; também, considera a possibilidade de, no caso de aliarem Portugal e França, a Inglaterra tentar impedir pela força essa opção;

4) a difusão, em Portugal, das ideias subversivas francesas. Considerando que essas «máximas jacobinas» estão, há muito, espalhadas em Portugal, recomenda que medidas convém preferentemente adoptar para deter a sua expansão. Atendendo à eventualidade do povo se levantar em massa, questiona a conveniência de se lhes fornecer armamento e munições.

Estabelecidos esses principais problemas, Vandelli crê necessário, para bem analisá-los, adoptar certos pressupostos de método que se reportam ao sentido científico com que devem ser tratados os assuntos políticos e financeiros, e que são:

1) resolver os problemas por escrito a partir de pareceres reduzidos a seus termos mínimos, organizando-se, para facilitar 


\section{Revista de História das Ideias}

a consulta, um arquivo sucinto e completo de toda a correspondência diplomática com Londres, Paris e Madrid;

2) reduzir o número de pessoas consultadas com o fim de as notícias permanecerem secretas; estabelecer a conveniência de se ouvir, ao mesmo tempo, alvitres de partidos opostos;

3) a decisão adoptada deve ser conclusiva, pois «o dilema é escabroso» (m.6/29).

\section{As necessidades financeiras}

Ao tratar das questões relativas ao posicionamento de Portugal face à Revolução Francesa, Domingos Vandelli parte da suposição de que para actuar internacionalmente um Estado precisa dispor de meios financeiros: «só a força militar e financeira assegura a conservação de um Estado e de seus objectivos primeiros» (m. 20/28) e, ainda mais claramente: «o dinheiro é o principal sustento para a guerra» (m. 15/28). Como Portugal não dispõe de dinheiro, só lhe cabe «aliar-se com a nação mais poderosa» (m. 20/28) que, para ele, é a França - mesmo porque «sem sistema, sem dinheiro e crédito para adquiri-lo, sem marinha e suficiente exército, sem aliado que o queira ou possa auxiliar parece impossível que resista à torrente dos franceses» (m. 8/30).

O bom político «não se deve sossegar em uma simples esperança mal fundada» (m. 31/28) mas deve encarar a realidade com lucidez: «deixemos cálculos e suposições aéreas.... Portugal é uma potência secundária, as suas finanças estão arruinadas, não tem crédito público para suprir o grande déficit nem gente suficiente para defender-se dos castelhanos e franceses, podendo contar-se por nulo o auxílio inglês» (m. 22/28).

Não deve portanto admirar que em quase todos os escritos encontremos sugestões de reforma financeira. A ilação é fácil: a defesa exige maiores ingressos financeiros que somente se obtêm por meio de reformas. A sobrevivência de Portugal depende pois directamente das finanças públicas serem reformadas rápida e eficazmente.

A reforma deve ter um sentido muito amplo, visando «economizar o que inutilmente se despende, obviar aos extravios, cobrar o que lhe deve, tirar melhor partido dos contratos e rendas, distribuir de forma mais proporcionalizada as despesas de forma a atender as precisões do Reino e das colónias» (m. 2/28).

Para levantar imediatamente dinheiro urge cunhar toda a prata das igrejas e hipotecar a dos particulares; desvalorizar a moeda; estabelecer uma capitação proporcional às rendas de cada um; vender todos os bens alodiais e da Corôa assim como os 
do clero regular; amortizar as comendas e capelas vagas, arrecadando para o Real Erário a importância da sua venda, impor grandes tributos ao luxo. Numa segunda etapa e para consolidar o crédito, amortizar pouco a pouco a dívida e estabelecer tributos moderados.

Vandelli enfrenta tanto o clero como a nobreza, impondo-lhes tributos e sacrifícios que pressupõem um ataque à ordem feudal (m. 37/38).

Para ele «não (deve) haver privilegiados, que todos os cidadãos concorram igualmente às precisões do Estado... (tão pouco) deve haver predilecção alguma (para a escolha dos cargos públicos) não se devendo atender aos empenhos» (m. 12/28).

Para sustentar o esforço de guerra faz-se necessário, portanto, «secularizar alguns bens eclesiásticos... tributando-os a todos» (m. 15/28). O confisco dos bens dos regulares (a exemplo do que fizeram José II e a república de Veneza) não deve ser encarado sob o prisma anti-clerical ou anti-religioso, mas segundo uma óptica regalista que subordina os interesses da Igreja ao Estado. Reconhece que "esse remédio é momentâneo porque, deduzindo-se a sustentação dos regulares e despesas para com as igrejas» (m. 2/30), o seu valor suprirá por pouco tempo a diminuição da receita - já que o Estado passará a arcar com essas despesas. $\mathrm{E}$ portanto um expediente de urgência no sentido de obrigar os eclesiásticos a contribuirem para as necessidades vitais do Estado (m. 7/29).

Preconiza a emissão de papel moeda, como «meio mais pronto e em nenhum modo oneroso à Real Fazenda» de se obter meio circulante, tanto mais que, se esses bilhetes forem aceites pela Real Fazenda e se esta os utilizar em seus pagamentos, «não haverá perigo que sofram descrédito com diminuição considerável de seu verdadeiro valor» (m.6/30).

Não cabe aqui analisar as providências que sugere para o fomento da agricultura. Seus projectos nesse sentido são bem conhecidos. Nos textos em que propõe uma reorientação estrutural da economia portuguesa, não se mostra radicalmente contrário às manufacturas (m. 14/29 e m. 8/29), embora queira para as mesmas uma maior carga fiscal (m. 7/30).

Em 1796/1797, Vandelli diagnostica, com lucidez e perspicácia, a crise do antigo regime português. Põe à luz a contradição básica desse período: para fazer face às novas despesas o Estado precisa aprofundar a reforma financeira iniciada por Pombal, levando-a, devido às circunstâncias do momento, muito mais adiante. Precisa taxar a Igreja e os privilegiados e tem de relançar a economia gerando riquezas que irão tornar, por sua vez, o Estado mais forte. Esta problemática, 


\section{Revista de História das Ideias}

cımo se sabe, não é só portuguesa e não se configura somente frente à ameaça da invasão francesa: Vandelli aproveita a conjuntura para diagnosticar as causas estruturais da crise. Para ele, formado à escola do pombalismo, é ainda através do despotismo esclarecido que a situação deve ser redressée. Por isso, exige ministros «fortes e enérgicos» (m.16/28) e é contra a convocação das Cortes, «senão na última extremidade, para resistir à invasão» (m. 29/28), tanto mais que «o Príncipe pode e tem todo o direito de (lançar) impostos sem anterior conhecimento do Povo» (m. 3/30).

Ouvidos os diversos pareceres, cabe ao Príncipe, «com superiores luzes, seguir e decidir o que mais e melhor convém à conservação do seu Trono e do fiel Povo que o Omnipotente foi servido confiar-lhe» (m. 28/28). Esses pareceres devem sobretudo ser sinceros, afastando-se os conselheiros «lisonjeiros que.... tem a máxima de não lhes dizer coisa alguma que os possa entristecer (e) ao contrário, procuram conservá-los em contínuas esperanças.... de que tudo o que tem aparecido de mal acabará bem, segundo os desejos dos mesmos Príncipes» (m. 31/28).

\section{O exercício do poder}

Vandelli considera «de suma ponderação a escolha de hábeis ministros em todas as ocasiões.... e principalmente nesta. As pessoas de letras são as mais próprias para as negociações....». Delineia o perfil do «activo, fleumático e prudente ministro que faça executar prontamente as ordens régias, respeitar o trono e manter os outros na subordinação»; a falta de um ministro como esse leva «à guerra interior dos partidos» (m. 30/28).

A «doença política do reino» (m. 15/29) é essa: o Príncipe não ter escolhido «uma pessoa hábil, zelosa, desinteressada, prudente, patriótica, inteligente e verdadeiramente sua amiga para Primeiro Ministro» (m. 2/29).

$\mathrm{Na}$ memória intitulada «Reflexões sobre o governo ministerial» (m.11/29) critica violentamente a maneira pela qual o poder é exercido, já que «os ministros de Estado constituem agora neste Reino uma espécie de aristocracia.... (e) sendo.... déspotas nas suas repartições, parecem arrogar a soberania absoluta, o que somente serve para fazer odioso o governo do Príncipe.... єsta aristocracia ministerial só pode ser coibida pela autoridade de um primeiro ministro (como Sully, Mazarin, Richelieu, Alberoni e Pombal) que fizeram a felicidade da nação e a glória aos seus monarcas» (m. 11/29); elogia também a Godoy (m. 12/28). 
É de espantar, nessa época, em Portugal, uma crítica tão violenta aos detentores do poder, crítica que atinge também o Príncipe, responsabilizado por não escolher bons colaboradores (m. 15/29) e por não governar com energia e firmeza.

Esses momentos críticos - os anos de 1795 e 1796 - «são preciosos.... e se devem aproveitar para a salvação do Reino, escolhendo-se um hábil primeiro-ministro para dirigir em chefe todas aquelas operações que conduzem à sua conservação» (m. 34/28). A imperiosa necessidade do monarca escolher um primeiro-ministro justifica-se por ele cumprir e obrigar o cumprimento das origens régias; o ministro inteiramente devotado ao Rei é uma extensão do próprio monarca.

Vandelli reporta-se sempre ao modelo pombalino de governo, lembrando que, em circunstâncias semelhantes às que estavam vivendo, foi Pombal quem evitou «a ruína geral de 1762» (m. 2/28). A relação entre D. José e Pombal é a melhor que se pode desejar entre um ministro e seu rei. Sebastião José, «electrizado pela mesma matéria eléctrica que causou o terramoto», pressentiu que já era tempo de seguir novo sistema, «iluminando com as ciências a Nação.... promovendo a agricultura, introduzindo as artes e manufacturas» (m. 18/28). Os atributos exigidos: «hábil, zeloso, desinteressado» reportam-se directamente as qualidades que Vandelli discerne no Marquês (m. 2/29).

Ao elogiar Pombal (m. 17/28), elogia também o Rei D. José, que «reduziu o seu reino do estado de abjecção e quase barbárịe ao estado mais florido nas ciências, nas artes, manufacturas e comércio»; intitula esta memória «Sobre o cuidado que, para o engrandecimento de Portugal, deve ter o Príncipe na escolha de seus ministros» (m. 17/28), e articula-a com outra, aparentemente contraditória, «Sobre as vantagens de decidir o Príncipe sem a interferência dos ministros». No fundo, Vandelli teme o confronto entre tendências opostas, que por falta de árbitro, venham a paralizar o governo e a reduzi-lo à inércia: «Enquanto o Príncipe não tomar deveras as rédeas do governo revestindo-se de toda a sua autoridade e por si mesmo resolver definitivamente e independentemente não haverá respeito ao trono, não terão fim as desordens e os contínuos sustos» (m. 37/28). Estas últimas linhas não devem ser entendidas como uma resistência à necessidade de entregar o poder a um primeiro-ministro, pois este transmitiria e imporia a vontade do soberano, seria o seu prolongamento, o súbdito que fizesse «executar prontamente as ordens régias (e) respeitar o trono» (m. 30/28).

O Marquês de Pombal é apresentado como um agente do rei, e, como se sabe, é assim que após a sua queda ele se defende dos processos: alega que se limitou a efectivar a vontade de D. José. Considera a Viradeira muito negativa; essa «mu- 


\section{Revista de História das Ideias}

dança de governo e a escolha do ministério de pessoas totalmente opostas as antecedentes por vingança ou particular animosidade reduziram Portugal ao estado actual de decadência» (m. 11/29).

Para substituir a equipa governamental no poder $\left({ }^{9}\right)$, que acusa de «ignorância, moleza ou fatalidade» (m. 38/28), Vandelli sugere o seguinte ministério: para Primeiro Ministro, o Morgado de Oliveira, para as Finanças, D. Rodrigo de Sousa Coutinho, para o Reino, o Bispo-Conde D. Francisco de Lemos, para a Marinha e Ultramar, o Marquês de Pombal ou Luís de Albuquerque ? para os Estrangeiros e Guerra, o mesmo Morgado de Oliveira (m. 10/28). Esta reforma é indispensável, «senão quem governa não estará seguro» (m. 10/28).

D. Rodrigo de Sousa Coutinho é pois o único ministro que deve permanecer: sendo um fiel discípulo de Pombal, é «uma acertada e prudente escolha». Deve dedicar-se exclusivamente às Finanças $\left({ }^{10}\right)$ pois «tem os conhecimentos necessários para que os impostos novos não piorassem a decadência económica» (m. 15/28) (11).

As críticas que Vandelli dirige ao ministério são muito violentas e devem-lhe ter criado sérias inimizades pela vida fora. Embora dirigidas ao Príncipe, supomos impossível evitar que se houvessem tornado conhecidas.

Culpa directamente o ministério «pela imperdoável omissão, pela indefinição desde 1790» (m. 12/28), pela má administração das finanças, pelo déficit, pelos desperdícios com a burocracia, pelo descontentamento do clero que sabe que o imposto que lhe vai ser cobrado será mal empregado, pela ruína do

(9) Cabe aqui recordar a composição desse ministério, segundo Vandelli tão pơco capacitado e eficaz. Em 1788, José Seabra da Silva torna-se titular da pasta do Reino; Luís Pinto de Sousa Coutinho (futuro Visconde de Balsemão) é responsável pela pasta dos Negócios Estrangeiros e Guerra, desde 1778: D. Rodrigo de Sousa Coutinho (futuro Conde de Linhares) é nomeado, em 1795, Secretário de Estados de Marinha e Ultramar; o Intendente de Polícia, Diogo Inácio Pina Manique, nomeado por Pombal, permanece no cargo até ser demitido por exiEência de Napoleão.

(10) A Secretaria de Estado dos Negócios da Fazenda foi criada em 1788 mas só passou a funcionar efectivamente em 1801.

(11) D. Rodrigo revelar-se-á defensor da aliança inglesa e será o negociador do Tratado com a Inglaterra de 1810 . Assim, a sua indicação por Vandelli constitui uma contradição que não sabemos como explicar. Possivelmente a análise unânime dos historiadores deste periodo que o consideram chefe do partido inglês e Antonio de Araújo, chefe do partido francês seja muito simplista. 


\section{Domingos Vandelli}

comércio, pelo armamento moroso, pelo material bélico de má qualidade, "pelo descuido em se fazer a paz ou obter a neutralidade, pelas inteligências secretas.... com Madrid, pela inclinação a favor da Inglaterra quando esta tem feito a nossa desgraça.... e pode ser que faça a última e irremediável pela venalidade da justiça» (m. 38/28).

\section{O abandono da aliança inglesa}

Vandelli preconiza que Portugal adira à aliança francesa por razões tácticas; a França será a vencedora e os ingleses, «desunidos e arruinados» pelo esforço de guerra (m. 6/29), não podem ajudar eficazmente o seu antigo aliado. Para sobreviver e se impor à Espanha, Portugal precisa da aliança e do auxílio francês.

Castela, desde João IV, nunca desistiu de absorver Portugal, e pensou concretizar essa intenção com a $\mathrm{Paz}$ de Basiléia (ms. 4/28 e 1/28). Nesse momento, a Espanha, «sempre pronta a atacar Portugal» (m. 3/28), está militarmente muito forte, com suas tropas na fronteira; «a essas pressões... somos incapazes de resistir» (m. 5/28).

Ao mesmo tempo em que Vandelli expõe as vantagens e a inevitabilidade de se aliar à França, tenta desmontar os argumentos favoráveis à manutenção da aliança inglesa, escrevendo que Portugal a rigor não vai trair a Inglaterra pois vai aliviá-la dos gastos com a aliança. Também, se Portugal conseguir manter a neutralidade, não a prejudicará em seu comércio - único interesse desse país, sem «outra aspiração que a mercantil» (m. 23/28).

Como tudo neste mundo, também a política externa (até então pró-inglesa) pode mudar sem que se perca a honra: «o decoro é relativo no tempo e as circunstâncias; como é o Bom, o Mal, porque o que se considera decoro, honra, útil em certas ocasiões não o são em outras» (m. 11/28).

Ele confessa que até um determinado momento foi favorável à aliança inglesa pois achava que a França estava prestes a sucumbir frente "ao exército dos realistas e chouans, às internas e contínuas dissenções, à falta de numerário, ao abatimento diário dos assinados e mandados, à carestia dos víveres, à falta de indústria e comércio, ao grande esforço do Império (austríaco) e do reino da Sardenha, auxiliado com dinheiro pelos ingleses, à grande força marítima dos mesmos e seus imensos recursos....» (m. 18/29). 
Mas esses factores se alteraram. A Inglaterra está falida nelo esforço de guerra, com uma enorme dívida pública que faz com que a oposição no Parlamento deseje a paz, sendo-lhe totalmente indiferente a preservação de Portugal.

Admite, pois, como certa e próxima a vitória francesa: deve-se portanto fazer a paz com essa potência o mais rapidamente possível, sendo este o único meio de Portugal se salvar. Essa paz deve ser concluída mesmo ao preço de concessões significativas na América ou na Ásia. Se possível, para fazer a França desistir da livre navegação do Amazonas, pode-se-lhe oferecer praças fortes na Ásia-Diu, Damão e Timor-que rendem menos do que custam a Portugal (m. 11/28).

Todo o raciocínio de Vandelli parte, como vimos, de uma avaliação muito pessimista da situação portuguesa: as finanças estão exauridas; a maior parte das colónias e fortalezas são incapazes de se defenderem; há insuficientes munições e apetrechos de guerra e marinha; faltam generais práticos; o exército é indiscip.inado, desorganizado, desanimado e descontente e, «longe de poder atender aos primeiros insultos»; falta um governo unido e forte capaz de implantar as directrizes adoptadas (m. 14/28 e 18/28); muitos portugueses estão imbuídos das ideias subversivas francesas, tanto nas cidades do Reino como nas colónias e o socorro que se pode esperar da Inglaterra é insignificante (m. 11/28).

A França considera acertadamente Portugal uma colónia inglesa. Sendo a fonte principal de todas as riquezas da Inglaterra, enriquecida com o ouro do Brasil (m. 14/30), os franceses impedirão que Portugal continue impunemente a favorecer a Grã-Bretanha (m. 14/30).

A ocupação espanhola trará consequências irremediáveis para Portugal. Mesmo na longínqua e improvável hipótese da França vir a perder a guerra, com a paz geral todas as potências vão considerar Portugal como uma antiga província da Espanha (m. 12/28). A paz com a França é também «o único meio para livrar-se dos insultos castelhanos» (m. 26/28).

Vandelli resume bem o «dilema escabroso» no seguinte texto, de 1796:

«Portugal precisa, sem demora, escolher entre a antiga ou a nova aliança. Se escolhe a antiga, é inevitável a perca do Reino porque presentemente não tem meios para se defender, sendo insuficiente o socorro prometido pelos ingleses. Se adopta a segunda possibilidade está também sujeito a perder-se, em razão da suposta má-fé de seus novos aliados. Mas os castelhanos já estão nas fronteiras, logo a pena é irremediável e pronta enquanto que o efeito da má-fé é mais vagaroso e dá tempo de renegociar. Assim me parece 
que entre os dois partidos o mais seguro para a conservação da monarquia é a aliança defensiva e ofensiva com a França e a Espanha. A monarquia portuguesa está por expirar. Se dirá à Europa que se deixou acabar... por falta de resolução?» (m. 9/28).

Vandelli dá-se conta da gravidade das consequências dessa opção e teme que a reacção inglesa ataque e saqueie as colónias, destruindo o comércio. Mas como o único fim daquela nação é o comércio e a exportação de suas manufacturas, pode-se compensá-la com a introdução de alguns produtos manufacturados em Portugal. E essa concorrência inglesa «obrigará os nossos fabricantes a aperfeiçoarem as suas manufacturas e os fará mais industriosos» (m. 7/28).

Para finalizar, os factores que leva em consideração são basicamer.te o lamentável estado de Portugal, sobretudo com relação ao exército e às finanças, a ameaça castelhana, a certeza de vitória francesa e a possibilidade de mais tarde se poder chegar a termos com a Inglaterra, impedindo o mal imediato da invasão do Reino pelos Espanhóis e a incorporação definitiva à Espanha.

\section{O perigo revolucionário}

Há uma tendência a desconsiderar o surgimento de uma consciência revolucionária em Portugal antes da invasão francesa. Costuma-se reconhecer somente a partir de 1817, com a conspiração de Gomes Freire, a oposição consciente e actuante ao Antigo Regime.

As cópias às Secretarias, do Intendente Pina Manique, são consideradas mais como zelo exagerado ou fanatismo anti-revolucionário, do que como testemunho da infiltração de ideias stibversivas entre os portugueses.

Vandelli dá muita atenção à opinião pública e está atento para as inclinações ideológicas que a mesma traduz. Acha que deve ser levada em conta, inclusive na escolha dos ministros: as qualidades de D. Rodrigo são atestadas pela mesma (m. 8/28). Leva a sério os boatos: «na Praça do Comércio correm os seguintes boatos....» (m. 6/28). Distingue as opiniões do povo e a dos grupos urbanos médios, nenhum dos quais tinha na época qualquer forma institucionalizada de expressar os seus anseios.

Refere-se às ideias subversivas que circulam durante o Antigo Regime sem as distinguir: utiliza o termo pejorativo de jacobino para englobar os liberais moderados ou avançados, os 
adeptos de reformas mais ou menos profundas, os partidários de uma revolução radical.

Pede à polícia que não esmoreça a sua vigilância, embora saiba que outros expedientes são necessários para conter a difusão desses princípios. O governo deve estar muito atento às pretensões populares, satisfazendo todas as que lhe pareçam justas para manter «o povo contente» e desinteressado «de uma mudança de governo....; (só) assim poderá.... defender o Príncipe» (m. 12/28).

A insurreição popular é uma possibilidade muito concreta: «a actividade da polícia, em prender alguns jacobinos e fechar-lhes os seus principais clubs, produziu um geral sossego nesta capital, onde podia haver algum susto de levantamento produzido por jacobinos, que agora estão atemorizados.... (m. 9/28). Não duvida que, «animado pelo mesmo espírito de entusiasmo.... àa França.... Portugal se levantaria em massa» (m. 7/29).

Uma noção interessante é a de que a ideologia revolucionária é a grande força da República Francesa. Numa época em que se insistia no carácter diabolicamente destruidor dessa ideologia, são poucos os que, como Vandelli, vêm nela uma força positiva de coesão social e nacional. Vandelli compara, nessa perspectiva, a força das ideias com a força das armas. «O génio revolucionário continua a fazer da guerra um instrumento de subversão social, abrasa no seu furor as monarquias, as repúblicas, os amigos, os inimigos da França, as potências neutras, as pacificadas e as beligerantes» (m. 16/29).

A força da Revolução Francesa reside «principalmente (em) suas máximas e princípios já espalhados entre a maior parte dos povos da Europa e da América....» (m. 11/28): «....A Itália é quase toda convulsionada, o Império está ameaçado, a Inglaterra não é muito longe disto, a Espanha está em grande perigo.... (assim como) Portugal....» (m. 16/29). Esses princípios revolucionários «fazem diminuir a cada dia aos monarcas considerável número de fiéis vassalos.... a República, em razão de seus princípios, ficará sempre superior às outras Nações beligerantes...., pois está estabelecida em princípios e leis admitidas e observadas pelo maior número de Povo» (m. 11/28). Vandelli, portanto, reconhece à República a legitimidade política que esta reivindica para si.

Relaciona também a má política do governo com a adopção do jacobinismo por parte do povo: «espalhou-se em todas as províncias e principalmente nesta capital, tendo muito aumentado pelo violento método de recrutar» (m. 12/28).

Para manter o povo satisfeito é necessário assegurar-lhe víveres, proteger o comércio, não atrasar os pagamentos, propor- 


\section{Domingos Vandelli}

cionar uma justiça rápida e honesta, não permitir privilégios nem agravá-lo de impostos muito pesados» (m. 12/28). Anteriormente não era necessário o prévio consentimento do povo para taxá-lo, «mas agora depois dos maus princípios espalhados pelos franceses, é de uma sã política evitar isto ao máximo» (m. 3/30).

Sobre a possibilidade de mobilizar toda a população contra o invasor, admite que «o baixo povo que vive ao dia a dia será 100 por cento contra quem é possuidor de bens e não quererá expor a sua vida para defender os bens que ele não possui, esperançado de melhorar de fortuna.... nunca este país se unirá em massa (contra os franceses)» (m. 12/28) - prognóstico que 1809-1810 provou errado. Contra os castelhanos, sim, os portugueses se uniriam, mas vindo as tropas francesas "precursoras da liberdade, acharão imenso número não só no baixo povo, mas até na nobreza de segunda ordem que se unirá às mesmas, como sltimamente sucedeu em Itália» (m. 8/30).

Há outra ameaça: embora compreenda que os espanhóis não desejem tropas francesas em seu território (nem mesmo para ajudar na invasão de Portugal) por medo da revolução que poderiam facilmente causar em Espanha, Vandelli pergunta-se em 1797: «tomando vigor os princípios franceses na Espanha, aquela nação, muito desgostosa do presente governo pode imitar a França.... (e) qual será a sorte de Portugal?» (m. 22/28).

Trata das possíveis consequências dos salários em atraso dcs dois mil oficiais, aprendizes e trabalhadores da Fundição, «aos quais facilmente se unirão todos os outros dos mais arsenais e os malcontentes e os jacobinos». Constata um estado de pré-insurreição "por falta de sua subsistência», devendo o governo intervir imediatamente através de providências financeiras «para acudir a esta ameaçada sublevação» (m. 36/28).

Salienta o poder do clero «influindo muito no Povo por influxo da religião» e repete que o povo, «escandalizado de tudo, murmura continuamente sem rebuço» (m. 38/28).

Desconheço outro texto português dessa época em que o perigo de uma sublevação popular é frontalmente encarada e justificada pelos abusos do governo e pela ideologia francesa. Para ele «não há outro remédio que ceder à força superior (esperando que a revolução perca o seu radicalismo); aos príncipes, só lhes cabe «reformar as suas nações, conservando os povos contentes» (m. 40/30).

Vandelli também leva em conta o patriotismo, essa noção nova e que se revelará tão vigorosa no momento da expulsão dos franceses. Segundo eles, «os jacobinos, ocultos debaixo do zelo patriótico, persuadem que a mudança do governo é a maior felicidade da nação, que só será feliz eximindo-se de tantas 
opressões» (m. 38/28). Esta frase parece-me resumir perfeitamente o impacto da Revolução Francesa nos países onde ainda vigora o antigo regime.

\section{Para concluir}

A leitura destes textos de Domingos Vandelli, redigidos para enfrentar o expansionismo revolucionário francês, mostra-nos as opções políticas existentes em Portugal, as suas tremendas limitações financeiras e militares, a sua reduzida margem de manobra diplomática. Também nos elucida quanto ao estado da opinião pública, especialmente com referência à penetração das ideias jacobinas e ao grau de desprestígio da autoridade. $\mathrm{O}$ governo do Reino está paralítico e acéfalo.

Mas também a figura humana de Vandelli ganha muito ao se conhecerem os seus escritos. Empenhado em deter o descalabro em que se encontra a nação, lúcido e insistente nos seus conselhos e pareceres, critica o antigo regime português como talvez nenhum seu contemporâneo. Denuncia os homens mais poderosos do país, responsabiliza o Príncipe por não se impor, reconhece ao povo sérias razões de queixa, admite a penetração das ideias francesas e acredita que para combatê-las seja necessário atender às solicitações populares, reformando a viciosa administração pública em muitos aspectos. Admite a eficácia desse sentimento revolucionário e não se ilude com o sentido que, uma vez despertado, tomará. Evidencia a força imbatível que o mesmo imprime às tropas francesas.

Vandelli tem sentido da realidade concreta, vê com largo escopo o panorama que o cerca, tem acuidade para enxergar o que as élites portuguesas não vêm e tem imaginação e audácia para apresentar soluções muito corajosas quando as reputa indispensáveis. Foram com certeza essas qualidades que o levaram ao exílio, em 1810. 